\title{
CHANGES IN GENE EXPRESSION DURING DRYING AND IMBIBITION OF DESICCATION SENSITIVE Magnolia ovata (A. St.-Hil.) Spreng. SEEDS ${ }^{1}$
}

\author{
ANDERSON C. JOSÉ², WILCO LIGTERINK ${ }^{3}$ ANTONIO CLAUDIO DAVIDE ${ }^{4}$, \\ EDVALDO A. AMARAL DA SILVA ${ }^{4}$, HENK W.M. HILHORST ${ }^{3}$
}

\begin{abstract}
Seeds of Magnolia ovata were dried to different water contents to assess the viability and transcript abundance of genes related to seed development, cell cycle, cytoskeleton and desiccation tolerance.The expression of development, cell cycle and cytoskeleton relative genes (ABI3, CDC2-like and ACT2) alone could not explain the germination behaviour of $M$. ovata seeds in relation to drying damage. Irrespective of their initial water content, the seeds performed in the same way during the initial period of germination and the deleterious effects of desiccation only occurred in later stages. Expression of PKABA1, sHSP17.5 and 2-Cys-PRX did not show a relationship with desiccation. However, the expression patterns of PKABA1 and SHSP17.5 suggested the participation of these genes in protective mechanisms during the imbibition of $M$. ovata seeds..
\end{abstract}

Index terms: desiccation tolerance, drying, gene expression, Magnolia ovata.

\section{ALTERAÇÕES NA EXPRESSÃO GÊNICA DURANTE A SECAGEM E EMBEBIÇÃO DE SEMENTES SENSÍVEIS À DESSECAÇÃO DE Magnolia ovata A. ST.-HIL.}

\begin{abstract}
RESUMO - Sementes de Magnolia ovata, foram secas a diferentes conteúdos de água para avaliação da viabilidade e da expressão de genes relacionados ao desenvolvimento, ciclo celular, citoesqueleto e tolerância à dessecação. A expressão de transcritos dos genes relacionados ao desenvolvimento, ciclo celular e citoesqueleto ( $A B I 3, C D C 2$-like e ACT2) não explicou o comportamento germinativo de sementes de $M$. ovata em relação aos danos ocasionados pela secagem. Aparentemente as sementes comportam-se da mesma maneira nos primeiros dias de embebição, independentemente do conteúdo de água inicial. A expressão dos transcritos dos genes PKABA1, sHSP17.5 e 2-Cys-PRX não mostraram relação com a dessecação, entretanto, o padrão de expressão de PKABA1 e sHSP17.5 sugere a participação destes genes em mecanismos de proteção durante a embebição de sementes de Magnolia ovata.
\end{abstract}

Termos para indexação: expressão gênica, Magnolia ovata, secagem, tolerância à dessecação.

\section{${ }^{1}$ Submetido em: 01/07/2008. Aceito para publicação em: 05/01/2009.}

${ }^{2}$ Eng. Florestal, Dr., Prof. Adjunto, Dept. Eng. Florestal - UFT, Campus Universitário de Gurupi, Cx. Postal 66, 77402-970, Gurupi - TO, acjose@ uft.edu.br
${ }^{3}$ Biólogo, Pesquisador, Dr., Laboratory of Plant Physiology, Wageningen University, Arboretumlaan 4, 6703 BD Wageningen, The Netherlands

${ }^{4}$ Eng.Agr., Dr., Prof. Adjunto, Dept. Eng. Florestal - UFLA, acdavide@ ufla.br, amaral@ufla.br. 


\section{INTRODUCTION}

Desiccation tolerance of seeds and pollen is a widespread phenomenon among higher plants. Orthodox seeds exhibit the ability to withstand removal of water from their tissues to permit storage at low temperatures and be kept in seed banks for periods of time varying from decades to thousands of years. However, not all species tolerate drying to such low water contents. Recalcitrant seeds have high water content at shedding and do not withstand desiccation down to $0.10 \mathrm{~g}$ $\mathrm{H}_{2} \mathrm{O} \cdot \mathrm{g}^{-1} \mathrm{dw}$ (Hong et al., 1996).

Although all seeds experience some reduction in water content after maturation, the limit tolerated by recalcitrant species is narrow, with considerable variation among species (Farrant et al., 1996). In some recalcitrant seeds like Camellia sinensis (Berjak et al., 1993), Quercus robur (Finch-Savage, 1992), Landolphia kirkii (Vertucci et al., 1995) an increase in desiccation tolerance is observed during development, A few recalcitrant species can also exhibit some degree of dormancy at shedding (Liu et al., 2005).

Studies of gene expression, associated with desiccation tolerance and sensitivity, have been used in order to understand the mechanisms leading to deterioration of recalcitrant seeds after drying (Faria et al., 2006). With the initiation of drying there is a shift in gene expression compelling seeds to a different physiological status, where genes coding for protective molecules have an important role in desiccation tolerant material (Ramanjulu and Bartels, 2002). Genes encoding for proteins associated with tolerance, especially those involved in metabolic changes (Avelange-Macherel et al., 2006), protection against oxidation (Pukacka and Ratajczak, 2005), and other putative protective molecules show a specific expression pattern during desiccation.

The phytohormone abscisic acid (ABA) is involved in the regulation of many complex plant physiological processes including seed development, seed dormancy, transpiration, adaptation to environmental stresses (Finkelstein, 2006) and plays an important role in seed desiccation tolerance. ABA INSENSTIVE 3/VIVIPAROUS 1 (ABI3/VP1) is a transcription factor that mediates ABA responses in seeds from a range of species (Parcy et al., 1994; Zeng et al., 2003). ABA acts through ABI3/VP1 during the later stages of seed development, which promotes seed maturation processes including storage reserve deposition, the acquisition of desiccation tolerance and dormancy (Li and Foley, 1997). Seeds of severe abi3 mutants in Arabidopsis accumulate less storage proteins, are desiccation-intolerant and germinate precociously. Studies with transgenic plants overexpressing
$A B I 3$ indicated that this gene is able to direct the expression of seed-specific genes in response to ABA in tissues other than seeds (Parcy et al., 1994).

Actin and tubulin are the major components of the plant cytoskeleton. Actin is required for correct cell-division, plate alignment and synthesis, cell shape determination, cellpolarity establishment, cytoplasmic streaming, organelle movement and tip growth (Meagher et al., 2005). The cell cycle is controlled by the molecular machinery that ensures the fidelity of DNA replication and responds to signals from both the external environment and intrinsic developmental programs. A central role in the regulation of the cell cycle is played by the cyclin-dependent kinases (CDKs) (De Veylder et al., 2001). CDKs govern, as in other eukaryotic organisms, the plant cell cycle (Inzé, 2005). Cell division is controlled by the activity of CDK complexes. In addition to their association with CYCs (Cyclins), the activity of CDKs is also regulated by other mechanisms, including activation of CDKs through phosphorylation. CDKs are also involved in the regulation of transcription and mRNA processing (Loyer et al., 2005).

Proteins kinases also play a critical role in the perception and transduction of cellular responses to environmental stresses (Holappa et al., 2005). PKABA1 is a serine/ threonine protein kinase belonging to the SnRK2 group. Its transcription is induced by $\mathrm{ABA}$ and occurs in embryos and seedlings. PKABA1 is transcriptionally up-regulated in response to environmental stress via changes in $A B A$ concentration in vegetative tissues and developing embryos of wheat (Holappa and Walker-Simmons, 1995). PKABA1 mRNA levels increase as ABA content increases in developing embryos and reach high levels at seed maturity. Levels remain high in isolated embryos treated with $A B A$ but decline in germinating seeds. PKABA1 is induced rapidly in seedlings when $A B A$ levels increase in response to environmental stress like cold temperature and osmotic stress (Holappa and Walker-Simmons, 1995). PKABA1-like genes have been identified in many plant genomes including Triticum aestivum (TaPK3), soybean (SPK3), Arabidopsis (SNRK2E) and Medicago truncatula (Holappa and WalkerSimmons, 1997) and may be associated with the acquisition of desiccation tolerance (Faria et al., 2006).

Reactive oxygen species (ROS) play a significant role in causing damage to living cells under severe stress conditions. To deal with oxidative stress, complex protective mechanisms have been evolved by plants to mitigate and repair the damage initiated by free radicals (Price et al., 1994). The expression of the 2-CYS PRX gene is up-regulated in Arabidopsis 
plants in response to salt stress and in response to pathogen infection (Rouhier et al., 2004; Charlton et al., 2005). These antioxidants can also remove damaging reactive oxygen species produced by products of desiccation and respiration during late embryogenesis, imbibition of dormant seeds and germination (Stacy et al., 1996).

Another group of plant proteins with synthesis associated with stress is formed by the heat shock proteins (HSPs). HSPs are divided into low molecular mass proteins of approximately 15-28 kDa (sHSPs) and high molecular mass proteins of more than $30 \mathrm{kDa}$ (HMM HSPs). sHSPs were first discovered as gene products whose expression is induced by heat and other forms of abiotic stresses. However, now their importance as molecular chaperones is generally accepted (Lee and Vierling, 2000).

This work aimed to study the expression of genes, at the mRNA level, related to seed development, cell cycle, cytoskeleton and desiccation tolerance during drying and subsequent imbibition of the desiccation sensitive seeds of Magnolia ovata (Magnoliaceae), a tree from the Brazilian Atlantic Forest, in order to better understand the mechanisms, leading to deterioration of recalcitrant seeds by desiccation and subsequent imbibition.

\section{MATERIALS AND METHODS}

\section{Plant material and desiccation conditions}

Magnolia ovata fruits were collected from 12 trees along the Rio Grande river near Lavras (State of Minas Gerais, Brazil), in September 2004. After collection, fruits were left at room temperature to allow the completion of dehiscence, which occurred between 3 to 4 days after collection. The red aril that covers the seed was removed by gentle rubbing on a mesh and rinsing with tap water. After cleaning, seeds were blotted dry with a paper towel to remove excess of water, and stored at $5^{\circ} \mathrm{C}$ in closed plastic bags. Seeds were deployed for experimental work within 2 months of harvest.

Desiccation was carried out over a 90\% (w/v) lithium chloride solution, providing a relative humidity of $11 \%$ at $20^{\circ} \mathrm{C}$. Water content was monitored every hour by the difference between initial weight of fresh and dried seeds. When seeds reached the estimated target water content, three samples were taken: one sample of 20 seeds for water content determination, one sample of 100 seeds for germination and one sample of 50 seeds for RNA extraction (Table 1). The latter seeds were frozen in liquid nitrogen and stored at $-70^{\circ} \mathrm{C}$ until processing.
TABLE 1. Treatments applied to Magnolia ovata seeds in order to study changes in gene expression during desiccation and after imbibition.

\begin{tabular}{ll}
\hline Sample & Treatment \\
\hline F0 & Fresh seeds (control, $\left.0.28 \mathrm{~g} \mathrm{H}_{2} \mathrm{O} \cdot \mathrm{g}^{-1} \mathrm{dw}\right)$ \\
PD0 & Partially dried seeds $\left(0.25 \mathrm{~g} \mathrm{H}_{2} \mathrm{O} \cdot \mathrm{g}^{-1} \mathrm{dw}\right)$ \\
D0 & Dried seeds $\left(0.10 \mathrm{~g} \mathrm{H}_{2} \mathrm{O} \cdot \mathrm{g}^{-1} \mathrm{dw}\right)$ \\
F2 & Fresh seeds after 2 days of imbibition \\
PD2 & Partially dried seeds after 2 days of \\
D2 & imbibition \\
F10 & Dried seeds after 2 days of imbibition \\
PD10 & Fresh seeds after 10 days of imbibition \\
D10 & Partially dried seeds after 10 days of \\
& imbibition \\
& Dried seeds after 10 days of imbibition \\
\hline
\end{tabular}

\section{Water content assessment}

Water content of whole seeds was determined gravimetrically of four replications of five seeds by oven drying at $103^{\circ} \mathrm{C} / 17$ hours (ISTA, 2005). Water contents were expressed on a dry weight basis $\left(\mathrm{g}_{2} \mathrm{O} \cdot \mathrm{g}\right.$ dry weight ${ }^{-1}$, or $\left.g \cdot g^{-1}\right)$.

\section{Seed germination and viability assessment}

Before germination seeds were pre-humidified by incubation on moist filter paper (Ø $85 \mathrm{~mm}$, Schleicher and Schuell 595, Dassel, Germany) in $9 \mathrm{~cm}$ Petri dishes for 24 hours with $5 \mathrm{ml}$ distilled water. Subsequently, seeds were surface sterilised in $1 \%$ sodium hypochlorite for 10 minutes, rinsed with distilled water and imbibed in $5 \mathrm{ml}$ of distilled water. Germination experiments were executed with four replicates of 25 seeds. Seeds were placed in $9 \mathrm{~cm}$ Petri dishes on two sheets of filter paper (Schleicher and Schuell 595). Seeds were incubated at alternating temperature $20^{\circ} \mathrm{C} / 10^{\circ} \mathrm{C}$ (day/night), with 8 daily hours of light.

A seed was regarded as germinated when the radicle protruded $2 \mathrm{~mm}$ through the seed coat. After 0, 2 and 10 days of imbibition, a sample of 50 seeds was taken for RNA extraction. These seeds were frozen in liquid nitrogen and stored at $-70^{\circ} \mathrm{C}$. Germination experiments were carried out for 80 days. Non germinated seeds after this period were evaluated by a cut test in order to assess viability of seeds. Seeds were regarded as dead if mushy, liquid or rotten endosperm was present. On the other hand, if a firm and white endosperm and embryo were present, seeds were scored as viable seeds (Goslin, 2002; ISTA, 2005) and reported as “dormant” seeds. 


\section{Total RNA isolation and reverse transcriptase PCR}

Total RNA was extracted from whole seeds (without the seed coat). It was not possible to isolate the embryo from the seed without severely damaging it. For each treatment, 50 seeds were frozen in liquid nitrogen and stored at $-70^{\circ} \mathrm{C}$. Seeds were ground with a mortar and pestle in liquid nitrogen and added to a tube containing $1 \mathrm{ml}$ of phenol:chloroform (5:1) plus TLE grinding buffer $(0.18 \mathrm{M}$ Tris, $0.09 \mathrm{M} \mathrm{LiCl}$, 4.5 mM EDTA, 1\% SDS, adjusted to $\mathrm{pH} 8.2$ ) and $5 \mu \mathrm{L}$ of $\beta$-mercaptoethanol that was added to the extraction buffer. After centrifugation, the upper phase was transferred to a new tube containing $1 \mathrm{ml}$ of phenol-chloroform (1:1), centrifuged again and the supernatant was washed with chloroform to remove any residual phenol. RNA was precipitated overnight at $-20^{\circ} \mathrm{C}$ in 0.1 volume $3 \mathrm{M}$ sodium acetate and 2.5 volume of $100 \%$ ethanol, and then resuspended in $20 \mu \mathrm{L}$ DEPC water. RNA quality was analyzed in $1.0 \%$ agarose gel electrophoresis, stained with ethidium bromide and quantified with a spectrophotometer (Eppendorf BioPhotometer, Eppendorf, Hamburg, Germany).

cDNA synthesis was performed using the iScript cDNA synthesis kit (Bio Rad, Hercules, CA, USA), according to the manufacturer's protocol. Reactions were prepared by mixing the total RNA with iScript reaction mix and iScript reverse transcriptase and performed in a thermal cycler (iCycler, Bio Rad, Hercules, CA, USA), as follows: 5 min at $25^{\circ} \mathrm{C}$; $30 \mathrm{~min}$ at $42^{\circ} \mathrm{C}$ and $5 \mathrm{~min}$ at $85^{\circ} \mathrm{C}$. A negative control for cDNA synthesis was also included, by omitting reverse transcriptase to the reaction.

\section{Primer design and quantitative real-time PCR}

Degenerate primers (Table 2) were designed based on gene sequences available in databases using the software Jellyfish version 3.2 (LabVelocity, Inc., Los Angeles, USA). Sequences amplified by PCR were cloned using pGemT vector (Promega, USA) following manufacturer's instructions, and sequenced. Sequences were annotated and deposited in GenBank at National Center of Biotechnology Information server. Specific primers were designed with the software Vector NTI10 (Invitrogen Coorporation, USA), based on gene sequences obtained after cloning and sequencing of partial cDNA products.

TABLE 2. Specific primers used in the real-time PCR reactions.

Gene

$$
\text { Forward }
$$

(sequences written 5' to 3')
Reverse

(sequences written 5' to 3')

\begin{tabular}{lcc}
\hline ABI3 & GCTTCTTTCTTTGGCAACACAATCC & AACCGCCATGCAAACACAACAGC \\
$A C T 2$ & TGCTGTGATCTCCTTGNCTCATACG & GAAGCTGCTGGAATCCATGAGACC \\
$C D C 2$-like & AGATGAGGGTGTTCCAAGCACAGC & CGTGGATTCTTGGCAAAATCTGG \\
$P K A B A 1$ & GAGATTTAGCGAGGATGAGGCAAGG & GATTTTCAAGCGCGGAGCTGG \\
$2-C Y S-P R X$ & CCTACGCCGAAGAGTTCGAGAAGC & CCTTTTCGGGTCTGCTATTATCGG \\
$s H S P 17.5$ & AGGGCTGAAGAAAGAGGAAGTCAGG & TTTTCCATCGCTGCCTTCACG \\
$18 S$ & TGACGGAGAATTAGGGTTCG & CCTCCAATGGATCCTCGTTA \\
\hline
\end{tabular}

Reactions were performed using an iCycler iQ instrument (Bio Rad, Hercules, CA, USA) with gene specific primers, cDNA and iQ SYBR green supermix (Bio Rad, Hercules, CA, USA). The amplification protocol consisted of $3 \mathrm{~min}$ at $95^{\circ} \mathrm{C}$; then 40 cycles of $15 \mathrm{~s}$ at $95^{\circ} \mathrm{C}$ followed by $1 \mathrm{~min}$ at $60^{\circ} \mathrm{C}$. A primer for $18 \mathrm{~S}$ gene was used as internal control to normalize the other products for analysis purposes. A negative control (negative cDNA) and a water control were used in every PCR plate. Real-time PCR evaluations were replicated four times for each treatment, derived from 2 biological replicates repeated twice. Values of fold change in gene expression (mRNA) in relation to the control (fresh seeds) were calculated using the $2^{-\Delta \Delta \mathrm{Ct}}$ method (Livak and
Schmittgen, 2001), and plotted in graphs for comparison. Data were compared by Scott and Knott test $(p \leq 0.05)$ (Scott and Knott, 1974).

\section{RESULTS AND DISCUSSION}

\section{The Magnolia ovata seed}

The true $M$. ovata seed consists of a woody seed coat (testa), a soft oily endosperm and a small but fully differentiated embryo (Figure 1). The average seed size was $0.97 \times 0.62 \times 0.42 \mathrm{~cm}$ (length $\mathrm{x}$ width $\mathrm{x}$ thickness) whereas the average embryo length was $0.9 \mathrm{~mm}$ and represented approximately $1 / 40$ of the total seed volume. 


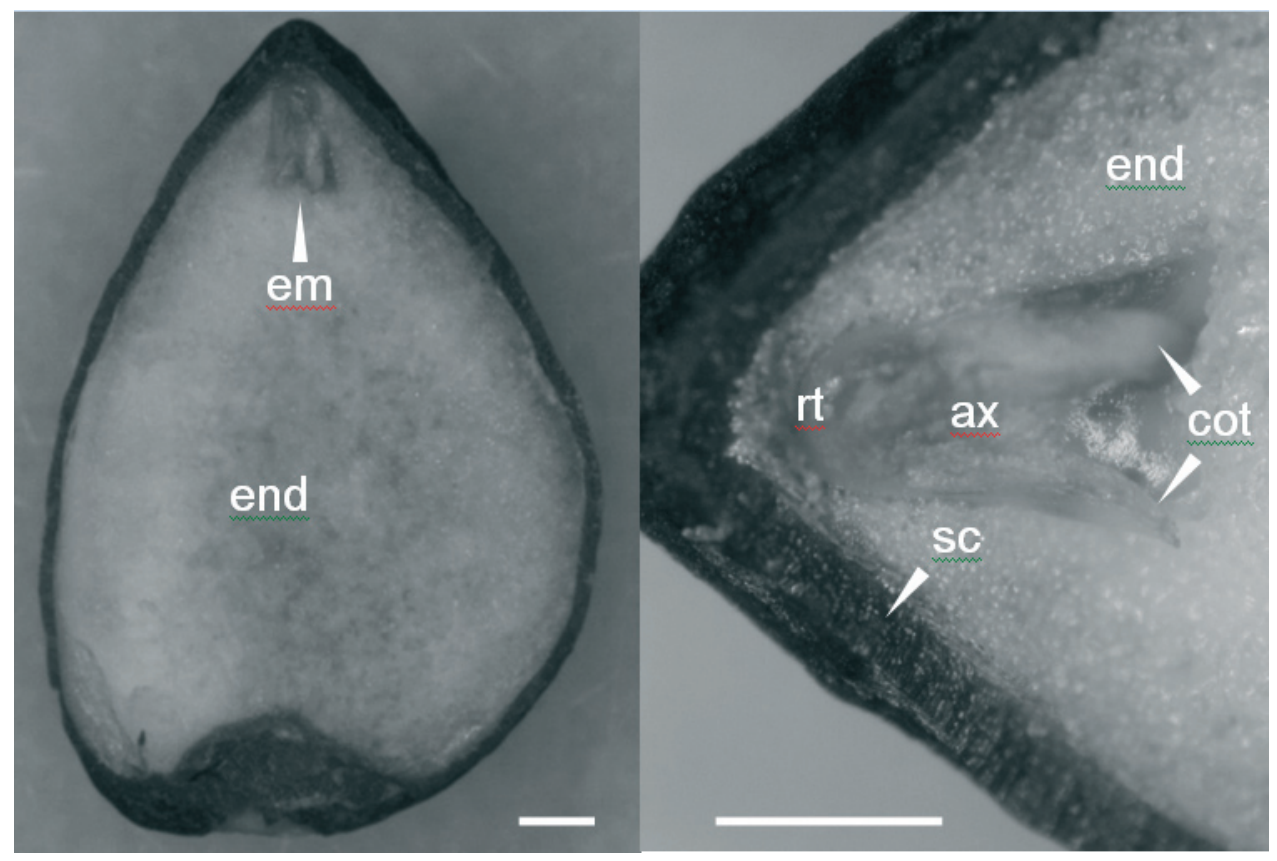

FIGURE 1. Transversal section of a $M$. ovata seed (A) and enlarged section with the embryo (B). em, embryo; end, endosperm; rt, radicle tip; ax, axis; cot, cotyledon; sc, seed coat. Bars represent 1 mm.

Viability of Magnolia ovata seeds after desiccation and Expression of genes related to seed development, cell cycle and cytoskeleton during drying and imbibition of Magnolia ovata seeds.

The viability of both fresh and partially-dried Magnolia ovata seeds was about $80 \%$. However, the proportion of dormant seeds was reduced after a partial drying treatment

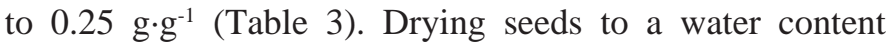
below $0.10 \mathrm{~g} \cdot \mathrm{g}^{-1}$ led to an almost complete loss of viability, although still some dormant seeds were detected at the end of the germination experiment.

TABLE 3. Effect of drying on germination and number of dormant seeds of Magnolia ovata. Final germination was scored after 80 days of incubation at $20 / 10^{\circ} \mathrm{C}$. Data are average of four replicates ( \pm standard deviation). Lower case letters in the same column indicate significance of difference based on Scott-Knott test $(\mathrm{p} \leq$ 0.05).

\begin{tabular}{lcccc}
\hline Treatment & $\begin{array}{c}\text { Drying time } \\
\text { (hours) }\end{array}$ & $\begin{array}{c}\text { Water content } \\
\left(\mathrm{g} \mathrm{H}_{2} \mathrm{O} \cdot \mathrm{g}^{-1} \mathrm{dw}\right)\end{array}$ & $\begin{array}{c}\text { Germination } \\
(\%)\end{array}$ & $\begin{array}{c}\text { Dormant } \\
(\%)\end{array}$ \\
\hline Fresh & 0 & 0.28 & $51 \pm 10.8 \mathrm{~b}$ & $27 \pm 2.9 \mathrm{a}$ \\
Partially dried & 2 & 0.25 & $72 \pm 8.0 \mathrm{a}$ & $7 \pm 2.0 \mathrm{~b}$ \\
Dried & 20 & 0.10 & $18 \pm 7.7 \mathrm{c}$ & $13 \pm 2.5 \mathrm{~b}$ \\
\hline
\end{tabular}

In general, differences in transcript abundance were not as pronounced as could be expected from comparable studies (Faria, 2006; Faria et al., 2007). Since the selected genes are expected to be expressed exclusively in the embryo, the use of whole seeds for RNA extraction may have resulted in a considerable dilution of embryonic RNA. The embryo volume is an estimated $1 / 40$ of the whole seed.

$A B I 3$ and ACT2 showed a similar expression pattern after desiccation (Figure 1A, B). Transcript abundance of both did not change significantly after drying the seeds (PD0 and D0 treatments) compared to the control (fresh seeds, F0). After imbibition, there was an increasing trend of the relative mRNA levels for both genes. $A B I 3$ expression was higher in fresh seeds imbibed for 2 days (F2) than in fresh seeds imbibed for 10 days (F10), whilst the relative levels of ACT2 did not differ in dried seeds imbibed for 2 days 
(D2) and dried seeds imbibed for 10 days (D10). The relative abundance of CDC2-like in F0 and PD0 did not differ (Figure $2 \mathrm{C})$. It was significantly down-regulated when seeds were dried to $0.10 \mathrm{~g} \cdot \mathrm{g}^{-1}$ and up-regulated after imbibition for 2 and 10 days in all treatments.
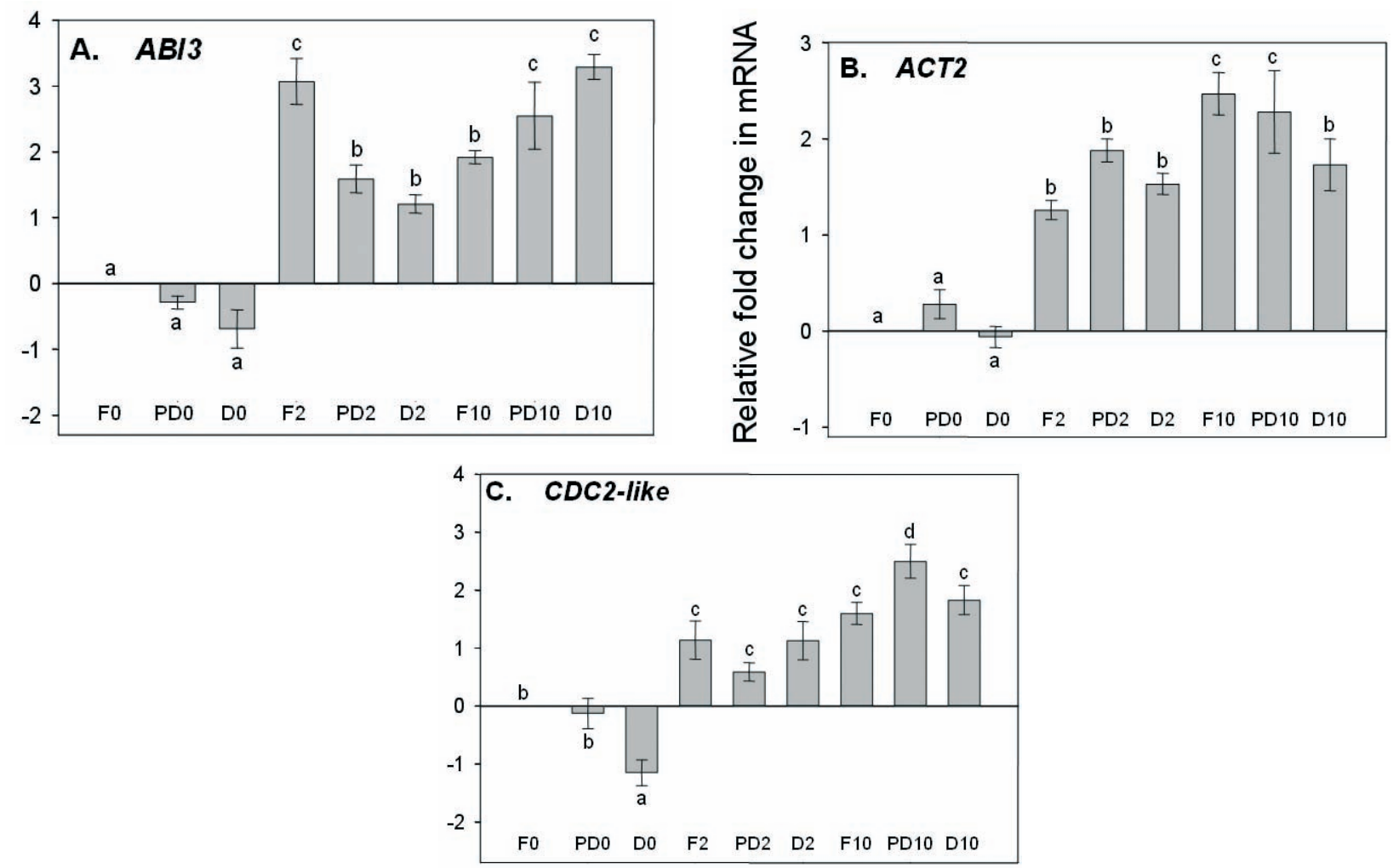

Treatment

FIGURE 2. Relative fold change in mRNA abundance of (A) ABI3 (accession number: FJ668600), (B) CDC2-like (accession number: FJ668602) and (C) ACT2 (accession number: FJ668597) in Magnolia ovata seeds after drying to different water contents and subsequently imbibition, as compared to fresh seeds (F0). Data show the mean \pm standard deviation of four replicates. Different lower case letters mean statistically significant difference based on Scott-Knott test $(p \leq 0.05)$.

In orthodox seeds, the maturation stage of development is characterized by desiccation. Concomitantly, seeds may enter a state of dormancy, which allows survival under unfavorable environmental conditions and ensures dispersal in place and time (Ingram and Bartels, 1996). Molecular studies of seed maturation in model species have revealed that it is driven mainly by three key genes: ABAINSENSITIVE3 (ABI3), FUSCA3 (FUS3), and LEAFYCOTYLEDON1 (LEC1) (Wobus and Weber, 1999). The expression pattern of ABI3 in Arabidopsis thaliana seeds is characterized by a continuous increase throughout development and transient expression during the first week of germination (Parcy et al.,
1994). On the other hand, Bassel et al. (2006), studying $A B I 3$ expression in tomato (Solanum esculentum) and Arabidopsis seeds, observed high transient expression of this gene during imbibition, prior to the completion of germination (i.e. radicle protrusion), but no expression in dry mature seeds. Our results show that the relative levels of $A B I 3$ transcripts remained approximately constant during drying (Figure 1A), whereas they increased in abundance during subsequent imbibition. However, the timing of increase of $A B I 3$ transcript abundance depended on the treatment. Rehydration from the driest state resulted in the slowest increase in $A B I 3$ transcript abundance. Although an increase in $A B I 3$ expression during germination 
has been observed in species such as tomato and Arabidopsis (Bassel et al., 2006) or yellow cedar (Zeng et al., 2003), there is no clear evidence of a participation of $A B I 3$ in signaling leading to the completion of germination. Moreover, most of the abi mutants in Arabidopsis show normal germination (Koornneef et al., 1984). Thus, it is plausible that ABI3 is participating in stress signaling during imbibition. It is important to note, however, that even with high expression of $A B I 3$ in dried seeds after imbibition, the vast majority of the seeds did not germinate, mainly because they had lost viability. These results are in accordance with Faria et al. (2007) who compared changes in $A B I 3$ expression in radicle tips during the loss and re-establishment of desiccation tolerance in germinated seeds of Medicago truncatula. Upon drying, desiccation intolerant radicles showed 15-fold higher $A B I 3$ transcript levels compared with desiccation tolerant radicles.

ACT2 expression did not change during drying, and showed an increase during imbibition. Transcript abundance remained high but dried seeds imbibed for 2 and 10 days displayed lower levels than those of fresh and partially dried seeds at 10 days of imbibition, thus apparently reflecting the loss of viability in the dried seeds. These results are partially in accordance with the expression of ACT7, a gene from the same family, in Arabidopsis seeds, where no expression was detected in developing embryos but high expression at seed maturity after drying. This high expression persisted during imbibition (McDowell et al., 1996). Changes in expression of ACT2 during seed development have not been reported so far. In vegetative tissues, water deficit causes a decrease in mitotic activity, which is attributed to the regulation of CDC2 genes and other cyclin-dependent kinase (CDK) proteins (Schuppler et al., 1998). These authors proposed that water-stress signaling acts on $C D C 2$ by increasing phosphorylation of tyrosine, causing a shift to the inhibited form and slowing cell production. In $M$. ovata there was a reduction in the levels of $C D C 2$ mRNAs when seeds were dried to low water contents (D0). However, when seeds were imbibed, the transcripts levels increased even in dried seeds, which have low viability.

The expression of $A B I 3, A C T 2$ and $C D C 2$ alone do not explain the germination behaviour of $M$. ovata seeds. It seems that the seeds, irrespective of their initial water content, perform in the same way during the initial period of germination whereas the deleterious effects of desiccation occur only later, since the germination of $M$. ovata seeds is very slow, with first radicle protrusion starting at 40 days after imbibition. These results suggest that seeds of this species may not be sensitive to desiccation to a water content of $0.10 \mathrm{~g} \cdot \mathrm{g}^{-1}$. Instead, seeds may become sensitive to imbibitional stress, leading to loss of viability, which was also observed in neem seeds (Azadirachta indica) (Sacandé, 2000).

\section{Expression of genes related to desiccation tolerance}

The expression pattern of PKABA1 and sHSP17.5 showed the same behaviour after drying to different water contents. There was a trend in reduction in the expression after desiccation, but it did not differ statistically from fresh seeds (Figure. 2A, C). The expression pattern of $P K A B A 1$ was similar to that of $A B I 3$ (Figure $3 \mathrm{~A}$ ), showing no differences after drying and an increase in transcript abundance after imbibition. In the same way, relative expression in fresh seeds imbibed for 2 days (F2) was higher than in those imbibed for 10 days (F10). The relative levels of sHSP17.5 increased with the time of imbibition, with no significant differences between the drying treatments. Drying fresh seeds to $0.25 \mathrm{~g} \cdot \mathrm{g}^{-1}$ (PD0) did not change the relative amounts of 2-Cys-PRX mRNA (Figure 3B) but a significant reduction occurred after drying to $0.10 \mathrm{~g} \cdot \mathrm{g}^{-1}(\mathrm{D} 0)$. There was no difference in transcript level before and after imbibition of fresh and partially dried seeds (F2 and PD2), but a clear reduction was observed after 10 days of imbibition (F10 and PD10). The 2-Cys- $P R X$ transcript levels in dried seeds remained the same after imbibition for 2 days (D2) but increased after imbibition for 10 days (D10) to the same value as observed in fresh seeds.

$P K A B A 1$ is involved in a signaling pathway by which ABA suppresses the induction of gibberellin responsive genes in cereal aleurone layers (Gomez-Cadenas et al., 2001). Its expression is up-regulated by ABA, dehydration, cold, and osmotic stress in other plant tissues (Holappa and Walker-Simmons, 1995). During wheat seed development the levels of PKABA1 mRNA increased, but decreased during imbibition of nondormant seeds and transiently increased during imbibition of dormant seeds (Johnson et al., 2002). PKABA1 was not up-regulated during drying of $M$. ovata seeds, but its expression was induced after imbibition, even in fresh seeds. It suggests the participation of ABAsignaling during the imbibition of $M$. ovata seeds. Seeds of some temperate recalcitrant species such as Aesculus hippocastanum (Tompsett and Pritchard, 1993) and Aesculus pseudoplatanus (Hong and Ellis, 1990) have been reported to have dormancy at shedding. Fresh seeds of $M$. ovata showed a high number of dormant seeds after 80 days of imbibition (Table. 3), which is in accordance with high expression of PKABA1 at 2 and 10 days of imbibition. 

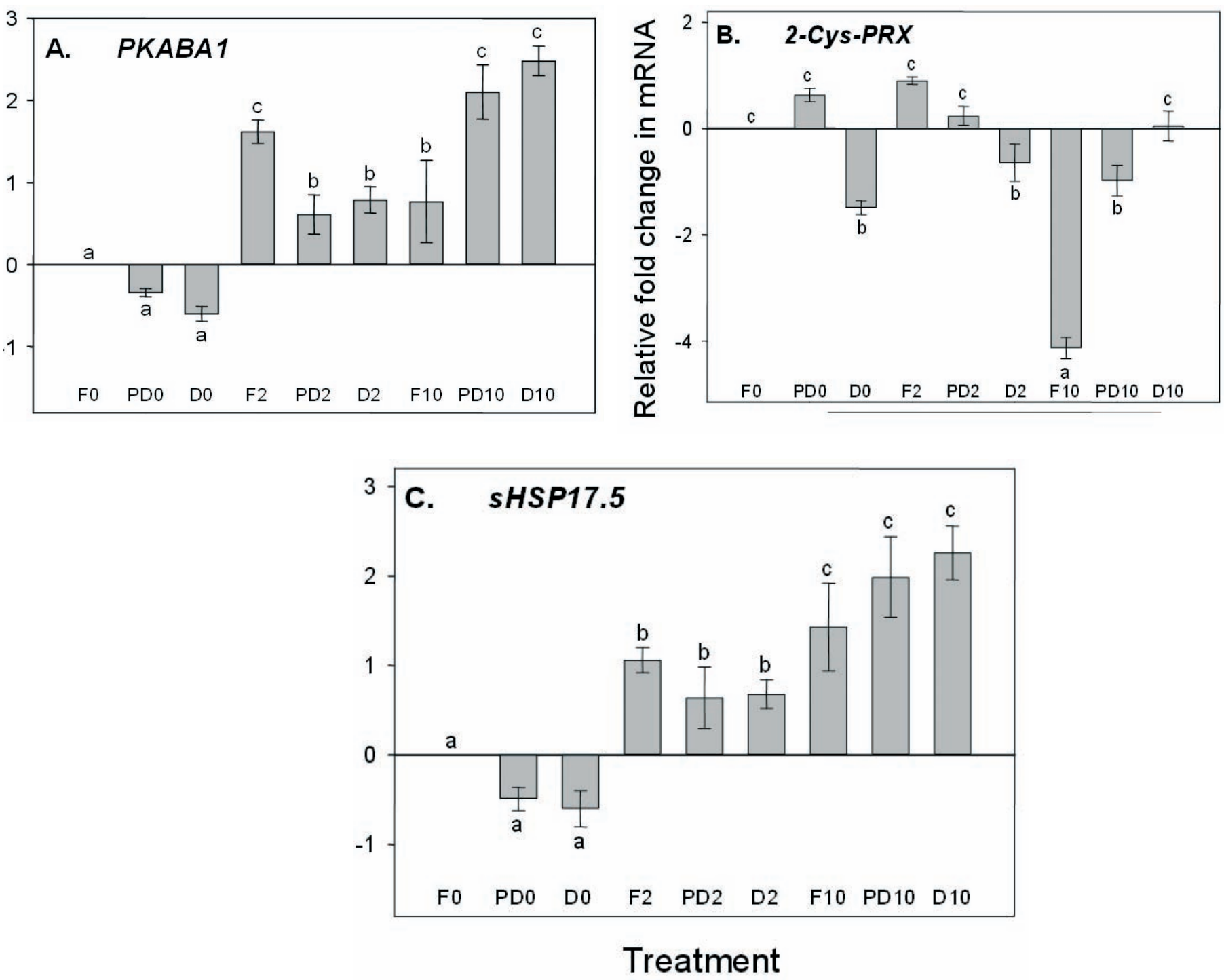

FIGURE 3. Relative fold change in mRNA abundance of (A) PKABA1 (accession number: FJ668599), (B) 2-Cys-PRX (accession number: FJ668601) and (C) sHSP17.5 (accession number: FJ668598) in Magnolia ovata seeds after drying to different water contents and subsequently imbibition, as compared to fresh seeds (F0). Data show the mean \pm standard deviation of four replicates. Different lower case letters mean statistically significant difference based on Scott-Knott test $(\mathrm{p} \leq 0.05)$.

PKABA1 and sHSP17.5 are genes related to desiccation tolerance, but in the present study they did not show any relationship with drying. Transcript abundance of these genes remained constant during drying, but was up-regulated after imbibition. This suggests the participation of these genes in protective mechanisms during imbibition. The ABI3 gene product is thought to activate expression of genes coding for specific small heat shock proteins during seed development (Rojas et al., 1999). Comparing the expression pattern of $A B I 3$ (Figure 3A) and sHSP17.5 (Figure 3C) a similar trend can be observed, with increasing expression during imbibition, which partly confirms the preposition of $\mathrm{ABA}$ signaling control of PKABA1 and sHSP17.5 expression.

Peroxiredoxins may protect barley embryos and aleurone cells against desiccation-induced free radical damage during late seed development and early imbibition (Stacy et al., 1996). The peroxiredoxin gene has previously been shown to be up-regulated during seed maturation 
and down-regulated during germination in Arabidopsis (Haslekås et al., 1998) and in Brassica oleracea (Soeda et al., 2005), and its expression is mediated by $A B I 3$ (Haslekås et al., 2003). In B. oleracea, expression of this gene differed between fast and slow-dried osmoprimed seeds. Our results show no differences in gene expression between fresh (F0) and partially-dried seeds (PD0). However, its expression was down-regulated when seeds were dried to $0.10 \mathrm{~g} \cdot \mathrm{g}^{-1}$ water content (Figure 3B). This gene appears to have some role in fresh and partially dried seeds (F2 and PD2) only during the first days of germination, since its expression was upregulated in F2 and PD2 treatments, while in dried seeds (D10) an increase in abundance of 2-Cys-PRX mRNA occurred only after 10 days of imbibition.

\section{CONCLUSION}

Desiccation sensitive seeds of Magnolia ovata generally displays similar patterns of abundance of $A B I 3, A C T 2, C D C 2$, PKABA1 and sHSP17.5 transcripts during imbibition with or without previous drying. Since the differences between dried and fresh seeds were so minor during $10 \mathrm{~d}$ of imbibition, we conclude that desiccation damage in this species is expressed at later stages of the germination process, e.g. at the time of radicle protrusion after $40 \mathrm{~d}$. The observed normal stress responses to drying suggest that the seeds may have become increasingly sensitive to another type of stress induced by lower moisture contents, e.g. imbibitional stress. Only expression of 2-Cys- $P R X$ was a clear discriminator of the drying conditions (Figure 3B). The lowest water content induced the highest level of expression as compared to the non-dried seeds.

\section{REFERENCES}

AVELANGE-MACHEREL, M. H.; LY-VU, B.; DELAUNAY, J.; RICHOMME, P.; LEPRINCE, O. NMR metabolite profiling analysis reveals changes in phospholipid metabolism associated with the re-establishment of desiccation tolerance upon osmotic stress in germinated radicles of cucumber. Plant, Cell \& Environment, v. 29. n. 4, p. 471-82, 2006.

BASSEL, G. W.; MULLEN, R. T.; BEWLEY, J. D. ABI3 expression ceases following, but not during, germination of tomato and Arabidopsis seeds. Journal of Experimental Botany, v. 57, n. 6, p. 1291-1297, 2006.

BERJAK, P.; VERTUCCI, C. W.; PAMMENTER, N. W. Effects of developmental status and dehydration rate on characteristics of water and desiccation-sensitivity in recalcitrant seeds of Camellia sinensis. Seed Science Research, v. 3, n. 2, p. 155-166, 1993.

CHARLTON, W.; MATSUI, K.; JOHNSON, B.; GRAHAM, I. A.; OHME-TAKAGI, M.; BAKER, A. Saltinduced expression of peroxisome-associated genes requires components of the ethylene, jasmonate and abscisic acid signaling pathways. Plant, Cell \& Environment, v. 28, n. 4, p. 513-524, 2005.

DE VEYLDER, L.; BEECKMAN, T.; BEEMSTER, G. T. S.; KROLS, L.; TERRAS, F.; LANDRIEU, I. VAN DER SCHUEREN, E.; MAES, S.; NAUDTS, M. INZÉ, D. Functional analysis of cyclin-dependent kinase inhibitors of Arabidopsis. The Plant Cell, v. 13, n. 7, p. 1653-1668, 2001.

FARIA, J. M. R. Desiccation tolerance and sensitivity in Medicago truncatula and Inga vera seeds. 2006. $135 \mathrm{f}$. Thesis (PhD in Plant Physiology) - Wageningen University, Wageningen.

FARIA, J.M.R.; LAMMERS, M.; LIGTERINK, W.; KODDE, J.; HILHORST, H.W.M. Alterations in gene expression and DNA during loss and re-establishment of desiccation-tolerance in germinating and germinated Medicago truncatula seeds. In: ADKINS, S.W.; ASHMORE, S.; NAVIE, S.C. (Ed.). Seeds. Biology, development and ecology: 8th ISSS Workshop on Seeds. Wallingford: CABI Publishing, 2007. p.50-56

FARRANT, J. M.; PAMMENTER, N. W.; BERJAK, P.; FARNSWORTH, E. J.; VERTUCCI, C. W. Presence of dehydrin-like proteins and levels of abscisic acid in recalcitrant (desiccation sensitive) seeds may be related to habitat. Seed Science Research, v. 6, n. 4, p. 175-182, 1996.

FINCH-SAVAGE, W. E. Seed development in the recalcitrant species Quercus robur L.: germinability and desiccation tolerance. Seed Science Research, v. 2, n. 1, p. 17-22, Mar. 1992.

FINKELSTEIN, R. R. Studies of abscisic acid perception finally flower. The Plant Cell, v. 18, n. 4, p. 786-791, 2006.

GOMEZ-CADENAS, A.; ZENTELLA, R.; SUTLIFF, T. D.; HO, T. H. Involvement of multiple cis-elements in the regulation of GA responsive promoters: Definition of a new cis-element in the Amy32b gene promoter of barley (Hordeum vulgare). Physiologia Plantarum, v. 112, n. 2, p. 211-216, 2001.

HASLEKÅS, C.; STACY, R. A.; NYGAARD, V.; CULIANEZ-MACIA, F. A. AND AALEN, R. B. The expression of a peroxiredoxin antioxidant gene, AtPER1, 
in Arabidopsis thaliana is seed-specific and related to dormancy. Plant Molecular Biology, v. 36, n. 6, p. 833845, 1998.

HASLEKÅS, C.; VIKEN, M. K.; GRINI, P. E.; NYGAARD, V.; ORDGARD, S. H.; MEZA, T. J.; AALEN, R. B. ABI3 mediates expression of the peroxiredoxin antioxidant AtPER1 gene and induction by oxidative stress. Plant Physiology, v. 133, n. 3, p. 1148-1157, 2003.

HOLAPPA, L. D.; WALKER-SIMMONS, M. K. The wheat abscisic acid-responsive protein kinase mRNA, PKABA1, is up-regulated by dehydration, cold temperature, and osmotic stress. Plant Physiology, v. 108, n. 3, p. 1203-1210, 1995.

HOLAPPA, L. D.; WALKER-SIMMONS, M. K. The wheat protein kinase gene, TaPK3, of the PKABA1 subfamily is differentially regulated in greening wheat seedlings. Plant Molecular Biology, v. 33, n. 5, p. 935-941, 1997.

HOLAPPA, L. D.; WALKER-SIMMONS, M. K.; HO, T. H. D.; RIECHERS, D. E.; BECKLES, D. M.; JONES, R. L. A Triticum tauschii protein kinase related to wheat PKABA1 is associated with ABA signaling and is distributed between the nucleus and cytosol. Journal of Cereal Science, v. 41, n. 3, p. 333-346, 2005.

HONG, T. D.; ELLIS, R. H. A comparison of maturation drying, germination, and desiccation tolerance between developing seeds of Acer pseudoplatanus L. and Acer platanoides L. New Phytologist, v. 116, n. 4, p. 589-596, Dec. 1990.

HONG, T. D.; LININGTON, S.; ELLIS, R. H. Seed storage behaviour: a compendium. Rome: IPGRI, 1996. (IPGRI Handbooks for Genebanks No. 4.)

INGRAM, J.; BARTELS, D. The molecular basis of dehydration tolerance in plants. Annual Review of Plant Physiology and Plant Molecular Biology, v. 47, p. 377403, 1996.

INZÉ, D. Green light for the cell cycle. The EMBO Journal, New York, v. 24, n. 4, p. 657-662, 2005.

ISTA. International rules for seed testing. Seed Science and Technology, v. 33, 2005. Supplement.

JOHNSON, R. R.; WAGNER, R. L.; VERHEY, S. D.; WALKER-SIMMONS, M. K. The abscisic acid-responsive kinase PKABA1 interacts with a seed-specific abscisic acid response element-binding factor, TaABF, and phosphorylates TaABF peptide sequences. Plant Physiology, v. 130, n. 2, p. 837-846, 2002.

KOORNNEEF, M.; REULING, G.; KARSSEN, C.M. The isolation and characterization of abscisic acid-insensitive mutants of Arabidopsis thaliana. Physiologia Plantarum, v. 61, p. 377-383, 1984.

LEE, G. J.; VIERLING, E. A small heat shock protein cooperates with heat shock protein 70 systems to reactivate a heat-denatured protein. Plant Physiology, v. 122, n. 1, p.189-198, 2000.

LI, B.; FOLEY, M. E. Genetic and molecular control of seed dormancy. Trends in Plant Science, v. 2, p. 384-389, 1997.

LIU, Y.; QIU, Y. P.; ZHANG, L.; CHEN, J. Dormancy breaking and storage behavior of Garcinia cowa Roxb. (Guttiferae) seeds: implications for ecological function and germplasm conservation. Journal of Integrative Plant Biology, v. 47, n. 1, p. 38-49, 2005.

LIVAK, K. J.; SCHMITTGEN, T. D. Analysis of relative gene expression data using real-time quantitative PCR and the $2^{-{ }^{-} C_{T}}$ method. Methods, v. 25, p. 402-408, 2001.

LOYER, P.; TREMBLEY, J. H.; KATONA, R.; KIDD, V. J.; LAHTI, J. M. . Role of CDK/cyclin complexes in transcription and RNA splicing. Cellular Signalling, v. 17, n. 9, p. 1033-1051, 2005.

MCDOWELL, J. M.; AN, Y. G.; HUANG, S.; MCKINNEY, E. C.; MEAGHER, R. B. The Arabidopsis ACT7 Actin gene is expressed in rapidly developing tissues and responds to several external stimuli. Plant Physiology, v. 111, n. 3, p. 699-711, 1996.

MEAGHER, R. B.; DEAL, R. B.; KANDASAMY, M. K.; MCKINNEY, E. C. 2005. Nuclear actin-related proteins as epigenetic regulators of development. Plant Physiology, v. 139, n. 4, p. 1576-1585, 2005.

PARCY, F.; VALON, C.; RAYNAL, M.; GAUBIERCOMELLA, P.; DELSENY, M.; GIRAUDAT, J. Regulation of gene expression programs during Arabidopsis seed development: roles of the ABI3 locus and of endogenous abscisic acid. The Plant Cell, v. 6, n. 11, p. 1567-1582, Nov. 1994.

PRICE, A. H.; TAYLOR, A.; RIPLEY, S. J.; GRIFFITHS, A.; TREWAVAS, A. J.; KNIGHT, M. R. Oxidative signals in tobacco increases cytosolic calcium. The Plant Cell, v. 6, n. 9, p. 1301-1310, 1994.

PUKACKA, S.; RATAJCZAK, E. Production and scavenging of reactive oxygen species in Fagus sylvatica seeds during storage at varied temperature and humidity. Journal of Plant Physiology, v. 162, n. 8, p. 873-885, 2005.

RAMANJULU, S.; BARTELS, D. Drought- and desiccationinduced modulation of gene expression in plants. Plant Cell 
and Environment, v. 25, n. 2, p. 141-151, 2002.

ROJAS, A.; ALMOGUERA, C.; JORDANO, J. Transcriptional activation of a heat shock gene promoter in sunflower embryos: synergism between $\mathrm{ABI} 3$ and heat shock factors. The Plant Journal, v. 20, n. 5, p. 601-610, 1999.

ROUHIER, N.; GELHAYE, E.; GUALBERTO, J. M.; JORDY, M. -N; DE FAY, E.; HIRASAWA, M.; DUPLESSIS, S.; LEMAIRE, S. D.; FREY, P.; MARTIN, F.; MANIERI, W.; KNAFF, D. B.; JACQUOT, J-P. Poplar Peroxiredoxin Q. A thioredoxin-linked chloroplast antioxidant functional in pathogen defense. Plant Physiology, v. 134, n. 3, p. 10271038, 2004.

SACANDÉ, M. Stress, storage and survival of neem seed. 2000. $124 \mathrm{f}$. Thesis (PhD in Plant Physiology) - Wageningen Agricultural University, Wageningen.

SCHUPPLER, U.; HE, P-H.; JOHN, P. C. L.; MUNNS, R. Effect of water stress on cell division and Cdc2-like cell cycle kinase activity in wheat leaves. Plant Physiology, v. 117, n. 2, p. 667-678, 1998.

SCOTT, A. J.; KNOTT, M. A. A cluster analysis method for grouping means in the analysis of variance. Biometrics, v. 30, n. 3, p. 507-512, 1974.
STACY, R. A. P.; MUNTHE, E.; STEINUM, T.; SHARMA, B.; REIDUNN, A. B. A peroxiredoxin antioxidant is encoded by a dormancy-related gene, Per1, expressed during late development in the aleurone and embryo of barley grains. Plant Molecular Biology, v. 31, n. 6, p. 1205-1216, Sep. 1996.

TOMPSETT, P. B.; PRITCHARD, H. W. Water status changes during development in relation to the germination and desiccation tolerance of Aesculus hippocastanum L. seeds. Annals of Botany, v. 71, n. 2 , p. 107-116, Feb. 1993.

VERTUCCI, C. W.; CRANE, J.; PORTER, R. A.; OELKE, E. A. Survival of Zizania embryos in relation to water content, temperature and maturity status. Seed Science Research, v. 5, n. 1, p. 31-40, Mar. 1995.

WOBUS, U.; WEBER, H. Seed maturation: genetic programmes and control signals. Current Opinion in Plant Biology, v. 2, n.1, p. 33-38, 1999.

ZENG, Y.; RAIMONDI, N.; KERMODE, A. R. Role of an ABI3 homologue in dormancy maintenance of yellow-cedar seeds and in the activation of storage protein and Em gene promoters. Plant Molecular Biology, v. 51, n. 1, p. 39-49, 2003. 